\title{
Shattering Tradition: Rorty on Edification and Hermeneutics ${ }^{1}$
}

Tracy Ann Llanera

\begin{abstract}
To de-essentialize, to break up the lump, to pick over these traditions and institutions one by one, and see what use they have for our present purposes - this is the path that Richard Rorty (1931-2007) navigates in order to make his mark in the realm of philosophical thinking. He ruptures intellectual discourse by being flagrantly antiphilosophical, as made manifest by his avoidance of the ironic act of asking essentialistic yet unanswerable questions such as What is being? What is human nature? What can we know for sure? Instead, Rorty restrategizes his approach toward our interpretation of the history of ideas so as to downplay the Sisyphean search for primordiality. This paper plays on three themes: edification, hermeneutics, and the philosophers of edification in the 20th century. It intends to show that even upon the death of philosophy as epistemology - or in Rortian terms, as mirror-imagery - the "Conversation of Mankind" ensues in fresher, better, more relevant ways.
\end{abstract}

Key words: Rorty, edifying philosophy, hermeneutics, death of philosophy

\section{$\mathrm{T}$} o de-essentialize, to break up the lump, to pick over these traditions and institutions one by one, and see what use they have for our present purposes $^{2}$ - this is the path that Richard Rorty (1931-2007) navigates in order to make his mark in the realm of philosophical thinking. He ruptures intellectual discourse by being flagrantly anti-philosophical: by avoiding the ironic act of asking essentialistic yet unanswerable questions, such as, What is being? What is human nature? What can we know for sure? Instead, Rorty restrategizes his approach toward our interpretation of ideas so as to downplay the Sisyphean search for primordiality; after all, he boldly exclaims that "philosophy" is just a pigeonhole into which different things are stuffed in

${ }^{1}$ This paper was presented in the panel sessions of the Philosophical Association of the Philippines, Inc. (PAP) National Conference on the theme "The Death of Philosophy Debating the End, Possibilities and Future of Thinking" at Miriam College, Quezon City last April 2011.

2 Richard Rorty, "Letter to Anindita Niyogi Balslev, August 1 1990,” in Anindita Niyogi Balslev, Cultural Otherness: Correspondence with Richard Rorty, 2nd ed. (An American Academy of Religion Book, 1999), 21. 
different centuries, and even in different universities in the same country at the same time. ${ }^{3}$

Rorty revaluates philosophy by believing that our problems can be conveniently distinguished into two ways: they are either attempts to get to the bottom of things, to mirror nature and achieve certainty; or, they are provocations for us to be more creative, even experimental, in our interpretations of our life-situations. Hence, he re-crafts a version of our intellectual tradition in a way that forces us to willfully confront the burden of deciding what kind of philosophy to deal with. This choice, to put it clearly, is something like this: do we opt to linger on esoteric, archaic notions fossilized in systematic philosophy, or do we choose the timely, pragmatic and interactive form of edifying philosophy?

This paper plays on three themes: edification, hermeneutics, and the philosophers of edification in the $20^{\text {th }}$ century as explored along the thinker's body of works. It intends to support the claim that even upon the death of philosophy as epistemology - or in Rortian terms, of philosophy as mirror-imagery - the story of philosophy advances in more relevant, and even pioneering directions.

\section{Systematic and Edifying Philosophy}

Systematic philosophy puts epistemology at its center. Built for eternity, it offers arguments designed to be intrinsically unassailable so as to make justification and defense unnecessary. The works of Aquinas, Descartes, Hobbes, Newton, Russell and Husserl imply that objectivity and rationality great epistemological virtues that are prized beyond superstition, agreement, or convention - truly exist, even if they may or may not be accessible through inquiry. But Rorty says that this kind of thinking is obsolete. ${ }^{4}$ Constructive philosophers have not effectively learned to contend with differences in contexts and cultural climates, for they refuse to fully embrace particulars, small-scale observations, and contingencies. Conversely, edifying philosophy

3 Richard Rorty, Take Care of Freedom and Truth Will Take Care of Itself: Interviews with Richard Rorty, 1st ed. (Stanford University Press, 2005), 97; hereafter cited as TCF. It is the acceptance of one's works in a canon of philosophical literature which determines a thinker's place in the industry of thought. A philosopher is somebody who thinks and writes with constant reference, implicit or explicit, to the problems formulated by Plato (forms) and Kant (phenomena and noumena). Ibid., 69. This is the reason why we can put the books of analytic philosophers - like Russell, Quine, and Davidson in the same shelf we place the works of Freud, Gadamer, and Ricoeur.

${ }^{4}$ Richard Wolin, "Richard Rorty in Retrospect," in Dissent, 57:1 (Winter 2010), 75. The linguistic turn's contribution has helped us shift from talk about experience as a medium of representation to talk of language as such a medium that has made it easier to set aside the notion of representation itself. Richard Rorty, The Linguistic Turn: Essays in Philosophical Method, (Chicago: University of Chicago Press, 1992), 373; hereafter cited as LT. Unfortunately, philosophers (especially analytic ones) have not set aside the quest of mirroring nature, remaining clammed within their old problems. They have failed to draw the necessary conclusions from the "linguistic turn" and remain ensconced in the outmoded paradigm of "representation". 
resists reification, and is suspicious of theories that claim to penetrate the essence of reality. The likes of Goethe, Kierkegaard, Santayana, James, Dewey, the later Wittgenstein and Heidegger, philosophize against unchallengeable commiseration. These thinkers are intentionally peripheral, believing that they can make the world a more interesting place by incessantly reconceptualizing it - by perpetuating the "Conversation of Mankind," rather than by uncovering objective truths. ${ }^{5}$ Edification, in this context, is the project of finding fresher and more fruitful ways of speaking.

The boundlessness of this sort of philosophy makes it perennially subject to ridicule for its recklessness. Edifying thinkers are often accused of cynicism, for they suggest that even when we have justified true belief about everything we want to know, we may have no more than conformity to the norms of the day. ${ }^{6}$ But Rorty thinks this accusation is a misunderstanding - for edifying philosophers do not kill philosophy; instead, they steer its route nondictatorially. They poeticize our familiar surroundings through the unfamiliar terms of their inventions - allowing us to come up with new aims, new words, or new disciplines - opening innovative possibilities with an enlarged horizon in mind. Edification takes us out of our old selves by the power of strangeness, to aid us in becoming new beings. ${ }^{7}$ Thus, our intellectual landscape can be transformed by hermeneutically linking the abyss of the old for the promise of a better venture for philosophy.

\section{Hermeneutics}

Philosophies of edification rely on acts of interpretation that are guarded from institutionalization. Hermeneutics is an expression of hope that the cultural space left by the demise of epistemology will not be filled - that our culture should become one in which the demand for constraint and confrontation is no longer felt. ${ }^{8}$ Even if the quest for certainty is abandoned, interpretation acts as our conceptual tool to adapt to the ungroundable, indefinite world. Rorty develops this vantage point through two Continental philosophers: Hans-Georg Gadamer (1900-2002) and Jean-Paul Sartre (19051980).

In Truth and Method, the Gadamerian "hermeneutic" signals a shift of interest from what can be gotten right once and for all to what can only be reinterpreted and recontextualized over and over again. ${ }^{9}$ The inherited Platonic-Aristotelian view states that the only way to be edified is to know what is out there; however, we can also say that the quest for truth is just one

${ }^{5}$ Wolin, "Richard Rorty in Retrospect," 75.

6 Richard Rorty, Philosopby and the Mirror of Nature (Princeton: Princeton University Press, 1979), 367; hereafter cited as PMN.

${ }^{7}$ Ibid., 360.

${ }^{8}$ Ibid., 315.

9 Richard Rorty, "Holism and historicism," in Philosophy as Cultural Politics: Philosophical Papers IV (Cambridge: Cambridge University Press, 2007), 182-183; hereafter cited as PCP. 
among the many ways in which we might be edified. ${ }^{10}$ There are many aspects of our human affairs that cannot be suitably explicated through one methodology or a specialized vocabulary. ${ }^{11}$ The human sciences - philosophy, art, and history - are, for example, avenues where truths are being communicated, but they cannot be verified through the scientific method. ${ }^{12}$ Hence, man can choose not to be enslaved with capturing reality, for this is only an image that can be subsumed under a possible variety of philosophical approaches.

Sartre, meanwhile, asserts that philosophy as epistemology denigrates the possibility of a more vivid interpretation of our lives. To see the aim of philosophy as truth - namely, the truth about the terms which provide ultimate commensuration for all human inquiries and activities - is to see human beings as objects rather than subjects, as existing en-soi rather than as both pour-soi and en-soi, as both described objects and describing subjects. ${ }^{13}$ Fossilizing interpretation means accepting a prescription for delimitation; when applied to the self in the idealization of conformity, one evades the obligation of choosing one's project or responsibility. Such attitude is self-alienating, for this is the urge to be rid of one's freedom of erecting yet another alternative theory or vocabulary. ${ }^{14}$ Danger exists when ultimate values are channeled and participants are objectified, for this attitude absolves people of responsibility and fails to recognize the fragility of moral situations:

Man pursues being blindly by hiding from himself the free project which is this pursuit. He makes himself such that he is waited for by all the tasks placed along his way. Objects are mute demands, and he is nothing in himself but the passive obedience to these demands. ${ }^{15}$

Thus, on both epistemological and ethical levels, the GadamerianSartrean lesson is that mirroring nature is but one of a myriad of possible

\section{PMN, 360.}

11 Gadamer explains that "the emergence of historical consciousness over the last few centuries is a much more radical rupture. Since then, the continuity of the Western philosophical tradition has been effective only in a fragmentary way. We have lost the naive innocence with which traditional concepts were made to serve one's own thinking." Hans-Georg Gadamer, Truth and Method, trans. Joel Weinsheimer and Donald G. Marshall (New York: Continuum, 1998) xxv.

12 Ibid., xxii.

13 PMN, 378. This existentialist view of objectivity presents a temptation to selfdeception insofar as we think that, by knowing which descriptions within a given set of normal discourses apply to us, we thereby know ourselves. PMN, 361. For Sartre, knowing is plainly a human activity: "Knowledge puts us in the presence of the absolute, and there is a truth of knowledge. But this truth, although releasing to us nothing more and nothing less than the absolute, remains strictly human." Jean-Paul Sartre, Being and Notbingness: An Essay on Phenomenological Ontology, trans. Hazel Barnes (London: Methuen, 1943) 297.

14 PMN, 376.

${ }^{15}$ Sartre, Being and Nothingness, 796. 
ventures. Interpretations that accommodate not only universal commiseration but also particular, intersubjective, and creative ones are more insightful. ${ }^{16}$ So being "hermeneutical" is not having a special method but simply casting about for a vocabulary which might help in responding to our problems - thereby adopting "hermeneutics" for the sort of by-guess-and-by-God hunt for a new terminology which characterizes the initial stages of any new line of inquiry. ${ }^{17}$ Edifying philosophical works then challenge paradigms - for a modification of language consequentially alters our concerns, sparking Copernican revolutions on the intellectual landscape.

\section{Philosophers of Edification}

Rorty once said: "I think that 'philosopher' is the most appropriate description for somebody who remaps culture - who suggests a new and promising way for us to think about the relation among various large areas of human activity." 18 Such a powerful role is consistent with the notion that there can neither be an abrupt cut nor eventual death of philosophy when we have stopped our search for the True, the Good, and the Beautiful. As long as there are thinkers who can reweave, refocus, or even transform our ways of acknowledging the affairs of mankind, philosophy can thrive even when dethroned of its all-encompassing pedestal. Thus, edifying philosophers can never end philosophy, but they can help prevent it from attaining the secure path of a science. ${ }^{19}$

For Rorty, the three noteworthy edifying philosophers in the $20^{\text {th }}$ century are Ludwig Wittgenstein (1889-1951), Martin Heidegger (1889-1976), and John Dewey (1859-1952). They have restructured our framework of understanding, reformulated forgotten insights, and redirected philosophical concerns. Wittgenstein attempted to overhaul philosophy by wanting nothing to do with eternal, captivating pictures; instead, his contextualization has highlighted our inability to represent reality through words. Heidegger supplemented this with the historical awareness of mirror-imagery by letting us "distance" ourselves from the Western intellectual lineage. Dewey wrote his polemics against tradition out of a vision of a new kind of community - one that does not depend on objective cognition, but on aesthetic enhancement. ${ }^{20}$

16 "The conceptual world in which philosophizing develops has already captivated us in the same way that the language in which we live conditions us. If thought is to be conscientious, it must become aware of these anterior influences. A new critical consciousness must now accompany all responsible philosophizing which takes the habits of thought and language built up in the individual in his communication with his environment and places them before the forum of the historical tradition to which we all belong." Gadamer, Truth and Method, xxv.

17 Richard Rorty, "Method, Social Science, Social Hope," in Consequences of Pragmatism (Minneapolis: University of Minnesota Press, 1982), 199; hereafter cited as CP.

18 Richard Rorty, "Thomas Kuhn, Rocks and the Laws of Physics," in Pbilosophy and Social Hope (New York: Penguin, 2000), 175; hereafter cited as PSH.

19 PMN, 372.

${ }^{20} \mathrm{PMN}, 12-13$. 
Wittgenstein denies the possibility of universalizing language. In his early years, he was enamored with the attempt to represent reality but eventually he claimed this as futile, suggesting that questions which we should have to climb out of our own minds to answer should not be asked ${ }^{21}$ for they are fruitless and undesirable. As Rorty recounts:

The Tractatus starts out by telling us that the problems of philosophy are posed "because the logic of our language is misunderstood," but by the time we get to the Philosophical Investigations Wittgenstein is mocking the idea that there is any such logic to study. ${ }^{22}$

Language is but a tool employed to cope with the world ${ }^{23}$ and we cannot hope for any magical element in any language that can lead us to the universal, nor can we dream that we can construct one that does. ${ }^{24}$ Wittgenstein thinks that it is a futile exercise to ask whether there is a universal codification or system for all languages, and it is better to see language-learning as the acquisition of a skill. ${ }^{25}$ What is integral is to see vocabulary as part of the development of human communities, subject to ever-continuing advancement. Wittgenstein is thus edifying not because he has solved the problem of language; rather, it is because he has shown us that we can sweep the objectiverelative debate under the rug for a less-conflicted way of speaking.

Heidegger also threw away his systematic project in favor of an edifying stance. He began his career with an ontological project that seeks the

21 Richard Rorty, "Antirepresentationalism, Ethnocentrism and Liberalism," in Objectivity, Relativism, and Truth, Philosophical Papers, Volume 1 (Cambridge: Cambridge University Press, 1991), 7; hereafter cited as ORT.

22 "Wittgenstein, Heidegger, and the Reification of Language," in Essays on Heidegger and Others, Philosophical Papers, Volume 2 (Cambridge: Cambridge University Press, 1991), 62; hereafter cited as EHO. Tractatus Logico-Philosophicus was published in 1921, while Philosophical Investigations was published posthumously in 1953.

23 Wittgenstein playfully states: "Ask yourself whether our language is complete; whether it was so before the symbolism of chemistry and the notation of the infinitesimal calculus were incorporated in it; for these are, so to speak, suburbs of our language. (And how many houses or streets does it take before a town begins to be a town?) Our language can be seen as an ancient city: a maze of little streets and squares, of old and new houses, and of houses with additions from various periods; and this surrounded by a multitude of new boroughs with straight regular streets and uniform houses." Ludwig Wittgenstein, Philosophical Investigations, trans. G.E.M. Anscombe (Oxford: Basil Blackwell, 1963), 8.

${ }^{24}$ For Wittgenstein, we are misguided when we think that there is one language that naturally supersedes another. It is enough that they are treated independently and able to investigate their occupations separately. For example, "The existence of the experimental method makes us think we have the means of solving the problems which trouble us; though problem and method pass each other by. An investigation is possible in connexion with mathematics which is entirely analogous to our investigation of psychology. It is just as little a mathematical investigation as the other is a psychological one." Ibid., 232. in ORT, 216

25 "Cosmopolitanism without Emancipation: A Response to Jean-Francois Lyotard," 
meaning of Being through what he calls an existential phenomenology. ${ }^{26}$ But as he grew dissatisfied with the ambitious, constructivist tendency that permeated his early writings, he eventually deviated from it. So that instead of doing "phenomenological ontology", he then attempted to "overcome" the "ontotheological tradition" that linked Aristotle to Hegel.27 Based on this perspectival turn, Rorty exclaims that "the West, Heidegger thinks, has been on a power trip ever since, with the Greeks, it invented itself." 28 Platonism is the claim that the point of inquiry is to get in touch with something like Being, or the Good, or Truth, or Reality — something large and powerful which we have a duty to apprehend correctly. ${ }^{29}$ But instead of being trapped, Heidegger chose to deconstruct and even go beyond the constraints of thinking, ${ }^{30}$ showing how the philosophical tradition could be reappropriated by seeing it as a series of poetic achievements: the work of Thinkers, people who "have no choice but to find words for what a being is in the history of its Being." 31 Although "truth" occupies an elegant place, it is only but a manifestation of Being - in other words, the quest for the universal that began thousands of years ago can be evaded and surpassed. Heidegger, by glorifying poetry for its greater access to higher, more profound truths unavailable to systematic philosophers, is powerfully edifying for showing us a detour to literature.

But out of the three, it is Dewey whom Rorty credits as his philosophical hero, for he not only distrusted the pointlessness of purely academic philosophy but also circumvented its concerns by focusing on the

${ }^{26}$ Martin Heidegger, Being and Time, trans. by John Macquarrie and Edward Robinson (Harper Perennial Modern Classics, 2008).

27 "Pragmatism without Method," in ORT, 71-72.

28 "Heidegger, Contingency, and Pragmatism," in EHO, 31.

29 Ibid., 27. Heidegger blames Plato and Aristotle for sedimenting the tradition of mirror-imagery in Western philosophy, which started out differently - for a deeper way of looking at "thinking" is as the originary connection between phusis and logos: of being as the emerging sway in its constant presence (a thing reveals itself) and the gathering together of the relation of one thing to another. In this light - of thinking as both a presence and a gathering - it is not only through the mind that Being can be accessible to man. Its unconcealment can happen through work: the work of the word as poetry, the work of stone in temple and statue, the work of the word as thinking, the work of the polis as the site of history that grounds and preserves all this. But this originary idea, as Heidegger argues, was forgotten because Plato and Aristotle interpreted phusis as a fossilized "idea". With idea, truth became correctness - and eventually, correspondence has become the basic principle of knowledge or truth. See Chapter IV: The Restriction of Being by Martin Heidegger, Introduction to Metaphysics, trans. by Gregory Fried and Richard Polt (Yale University Press, 2000), 98-221.

30 Heidegger explains that this anti-Platonic stance is an imperative turn due to the historical progress of philosophy: "Throughout the history of philosophy, Plato's thinking remains decisive in its sundry forms. Metaphysics is Platonism. Nietzsche characterizes his philosophy as reversed Platonism. With the reversal of metaphysics that was already accomplished by Karl Marx, the uttermost possibility of philosophy is attained. It has entered into its end. To the extent that philosophical thinking is still attempted, it manages only to attain an epigonal renaissance and variations of that renaissance." Martin Heidegger, "The End of Philosophy and the Task of Thinking," in Basic Writings, trans. by Joan Stambaugh (Harper Perennial Modern Classics, 2008), 433.

31 "Philosophy as Science, as Metaphor, and as Politics," in EHO, 9. 
realm of politics, education, ethics, and culture. From Hegel, he learned to historicize everything, ${ }^{32}$ but observed that ideas and movements that had begun as instruments of emancipation (Greek metaphysics, Christianity, the rise of the bourgeoisie, the Hegelian System) had typically, over the course of time, turned into instruments of repression - into parts of "the crust of convention." This emboldened Dewey to think that "absolute truth" was such an idea and that the pragmatic theory of truth was "true in the pragmatic sense of truth: it works, it clears up difficulties, removes obscurities, puts individuals into more experimental, less dogmatic, and less arbitrarily skeptical relations of life." 33 And since philosophers were never going to be able to see things under the aspect of eternity, they should instead try to contribute to humanity's ongoing conversation about what to do with itself. Organic development due to the vitality of existence comes from the exchange of the arts and the sciences; hence, we must concentrate on the conscientious fortification of socially-constructed and modifiable inventions like "democracy" or "education," which enable the formation of a social vision for the next generation. The bottom line is that we ought to shrug off transcendental powers or universal truths - for there are no such things - in order to organize ourselves and see the utopian possibilities of a future we can create. ${ }^{34}$

\section{Epilogue}

Philosophy as operative upon Rorty's interpretation of hermeneutics and edification is an exciting reading altogether, for it participates in the "Conversation of Mankind" without succumbing to our temptation to hypostatize - the sin which so many thinkers have fallen into in their attempt to classify and organize all thought. By demystifying and shattering tradition piece by piece through the provocations of anti-essentialist thinkers, we are then led to better appropriate and appreciate the complexity and intricacy of our affairs, without hampering the possibility of participation and action - truly a Rortian challenge, through and through.

Department of Philosophy, University of Santo Tomas, Philippines

32 Richard Rorty, "John Searle on Realism and Relativism," in Truth and Progress, Philosophical Papers, Volume 3 (Cambridge: Cambridge University Press, 1998), 77-78; hereafter cited as TP. To be Hegelian means to treat cultural developments as simply temporary stopping places for the World-Spirit. "Dewey's Metaphysics," in CP, 85. Rorty believes that "with Hegel, intellectuals began to switch over from fantasies of contacting eternity to fantasies of constructing a better future. Hegel helped us to start substituting hope for knowledge." "The End of Leninism, Havel, and Social Hope," in TP, 233.

33 "John Searle on Realism and Relativism," in TP, 77-78.

34 Ibid., 77-78. Dewey thinks that the mind's function is to creatively project new and more complex ends - to free experience from routine and from caprice. The pragmatic lesson is not the use of thought to accomplish purposes already given either in the mechanism of the body or in that of the existent use of society, but the use of intelligence to liberate and liberalize action. John Dewey, "Theories of Knowledge (1916)," in Pragmatism: A Reader, ed. Louis Menand (New York: Vintage Books, 1997), 228-229. 


\section{References}

Balslev, Anindita Niyogi, Cultural Otherness: Correspondence with Richard Rorty, 2nd ed. (An American Academy of Religion Book, 1999).

Gadamer, Hans-Georg, Truth And Method, 2nd ed., trans. Joel Weinsheimer and Donald G. Marshall (Continuum, 2005).

Heidegger, Martin, Basic Writings (Harper Perennial Modern Classics, 2008). , Being and Time, trans. by John Macquarrie and Edward Robinson, (Harper Perennial Modern Classics, 2008). , Introduction to Metaphysics, trans. by Gregory Fried and Richard Polt, (Yale University Press, 2000).

Menand, Louis ed., Pragmatism: A Reader (New York: Vintage Books, 1997).

Rorty, Richard, Contingency, Irony, and Solidarity (Cambridge: Cambridge University Press, 1989). Consequences of Pragmatism (Minneapolis: University of Minnesota Press, 1982). Essays on Heidegger and Others, Philosophical Papers, Volume 2

(Cambridge: Cambridge University Press, 1991). , The Linguistic Turn: Essays in Philosophical Method, (Chicago: University of Chicago Press, 1992). Philosophy as Cultural Politics: Philosophical Papers IV (Cambridge: Cambridge University Press, 2007). Philosophy and the Mirror of Nature (Princeton: Princeton University Press, 1979). , Philosophy and Social Hope (New York: Penguin, 2000). Objectivity, Relativism, and Truth, Philosophical Papers, Volume 1 (Cambridge: Cambridge University Press, 1991). Take Care of Freedom and Truth Will Take Care of Itself: Interviews with Richard Rorty, 1st ed. (Stanford University Press, 2005). , Truth and Progress, Philosophical Papers, Volume 3 (Cambridge: Cambridge University Press, 1998).

Sartre, Jean-Paul, Being and Nothingness: An Essay on Phenomenological Ontology, trans. by Hazel Barnes (London: Methuen, 1943).

Wittgenstein, Ludwig, Philosophical Investigations, trans. by G.E.M. Anscombe (Oxford: Basil Blackwell, 1963).

Wolin, Richard, "Richard Rorty in Retrospect" in Dissent, 57:1 (Winter 2010), 73-79. 